\title{
SELECTION OF OPTIMAL AIR POLLUTION CONTROL STRATEGIES
}

\author{
Avinash P. Deshmukh ${ }^{1}$, M. Srinivasarao ${ }^{2}$ \\ ${ }^{1}$ Associate professor, Department of Chemical Engineering; Faculty of Technology, Dharmsinh Desai University, \\ College road, Nadiad, Gujarat, India, 387001 \\ ${ }_{2}^{2}$ Professor, Department of Chemical Engineering; Faculty of Technology, Dharmsinh Desai University, College road, \\ Nadiad, Gujarat, India, 387001
}

\begin{abstract}
Sustainable development needs social, economic, energy and environmental sustainability. We propose a model to minimize the total cost consisting of economic cost of pollution control equipment, health cost because of pollutants emissions. We developed a Mixed Integer Non Linear Programming (MINLP) based model for selection of optimal air pollution control strategy. The model considers multiple pollutants, multiple emission sources and multiple control equipments. Constraints like budget and efficiency of control equipment are included in the model. Affect of emission norms on total cost is discussed. The efficacy of the proposed model is explained by considering simulation case studies of a typical cement plant and a thermal power plant.
\end{abstract}

Keywords: sustainable development, economic cost, environmental cost, mixed integer non linear programming, optimization.

\section{INTRODUCTION}

Intensified interventions into the environment have led to air, water, and land pollution. Findings of world health organization, estimate that every year $8,00,000$ people die prematurely from diseases caused by outdoor air pollution (Akbar et al. 2003). In last one and half decades governments all over the world started taking steps towards pollution prevention and control for sustainable development.

To reduce industrial air pollutant emissions pollution prevention (P2) and/or pollution control (PC) techniques are used. Pollution prevention is more desirable compared to end of the pipe treatment techniques (Hossain et al. 2008; Mahmoud and Halwagi 1998). Development of green technologies based on principles of green chemistry is pursued extensively in the recent past. Methods are proposed to identify potential pollution problems at design stage and identify operating conditions for pollution prevention (Douglas 1992; Chen and Feng 2005). Carvalho et al. (2009) proposed a method to generate, screen and identify alternatives for pollution prevention in continuous and batch processes. Wessberg et al. (2008) proposed measures to prevent potential accidental emissions resulting from abnormal and unexpected events at industrial sites by using environmental risk analysis.

Pollution prevention is technically not possible in some industries. So, it is unavoidable to release air pollutants into atmosphere which effect human beings and ecology. Among all air pollutants, particulate matters attracted attention of researchers. Particles smaller than $2.5 \mu \mathrm{m}$ (PM2.5) causes respiratory and cardiovascular diseases. Electrostatic
Precipitators (ESP), Cyclone separators, Fabric Filters (FF) etc. are used by industries to control particulate matter emissions into atmosphere (Rao 1994; Jiao and Zheng 2007; Shanthakumar et al. 2008). Recent studies suggest utilisation of hybrid technologies that incorporate the best features of control equipments to overcome limitations of single air pollution control equipment (Cora and Hung 2002 ; Ortiz et al. 2007). Similarly, the removal techniques of gaseous pollutants like oxides of sulphur (Lee et al. 2005), oxides of Nitrogen (Mok and Lee 2006) and other odours compound (Couvert et al. 2006) also has been evolved (Mohanty et al. 2009; Jeona et al. 2008)

On the other hand, optimization has become a major enabling area and evolved from a methodology of academic interest into a technology that has continues to make a significant impact (Biegler and Grossmann 2004). Since mid of $20^{\text {th }}$ century efforts are been made to apply mathematical programming for air pollution control. Kohn (1969) has described a linear programming based optimisation procedure for reduction of pollutant to prescribed norms with available control devices and varying production rate. However, the method does not focus on optimal selection of control devices. Recent studies take into account economic as well as environmental impact into consideration using multiple objective optimizations for improved design and operation throughout the whole life cycle. This approach provides a potentially powerful decision making tool which may help process industries identify sustainable options for the future (Azapagic and Clift 1995, 1999). An optimization model for selection of suitable control option to minimize pollution load and maximize the profits has been described by Shaban et al. (1997).The existing optimization models consider economic cost and various constraints like 
pollutant emission norms. A multi-objective optimization strategy to identify the sustainable design of utility systems that satisfy both economic and environmental goals is developed. The mixed integer linear programming (MILP) model combines the minimization of costs with minimization of environmental impact that is assessed in terms of life cycle (Papandreou and Shang 2008). Chandra et al. (2009) proposed a mathematical model that described cost analysis of power generation from coal based power plant. The model considered quality of coal fed, installation cost, energy cost and environmental cost in terms of ESP efficiency. However, the models reported did not consider health cost due to emission of air pollutants in the objective functions for optimal selection of control options.

Exact quantification of environmental and social cost due to emissions is a major challenge. Swanson et al. (1996) proposed a chemical ranking and scoring method as a screening tool to provide a relative assessment of chemical hazards to human health and environment. This is done by combining measures of chemical toxicity pertaining to both human health and the environment with chemical release amounts and information on environmental persistence and bioaccumulation. Akbar et al. (2003) proposed method that assess and value the adverse health impacts of exposure to air pollutants reveal the magnitude of the costs to society. The estimation of health impact due to air pollutants depends on various factors. Health cost estimation and quantification methods are broadly based on a) concentration response functions and compounding factors b) effect of acute or chronic exposure to the pollutants c) dose response studies and d) medical costing using pollutant tracing. Concentration response function and compounding factors based method develops the relationship between the variety of diseases and illness caused by air pollution and variations in air pollutant concentrations (concentration response functions). In addition to the concentrations, the other major factors responsible for the health effect estimation including demographics, seasonal factors (compounding factors) are also taken in to consideration. Health cost estimation of air pollution due to road-traffic, the 'at least' approach (Filliger et al.1999) includes emission inventories and receptor studies where care has been taken that the estimation of impact shall not be overestimated and attributed 'at least' to air pollution. Economic health impact due to air pollution by' value of statistical life' approach (Lvovsky et al. 1998) includes capacity of money trading by people using terms like willingness to pay (WTP) and value of a statistical life (VOSL) to avoid a statistical premature death. The age effects, underlying health conditions and social cost have also been taken into consideration. The VOSL is also linked with fractions of years of healthy life lost as a result of illness or disability which is reported as Disability-Adjusted Life Years (DALYs). Method of medical costing using pollutant tracing (Friedrich et al. 2001) involves dispersion studies of the air pollutants right from the source till its final impact.
In this paper, a MINLP based optimisation program for selection of optimal air pollution control strategy has been developed. The objective of the program is to minimise the total cost consisting of installation and operating cost of pollution control equipment, health cost due to emissions and benefits obtained due to resource recovery. Effect of regulatory norms on the total cost is presented after taking various constraints like available budget and maximum reduction efficiency of control equipments. The efficacy of the proposed model in the selection of optimal air pollution control strategy is illustrated by considering simulation case studies of a typical cement plant and a thermal power plant. The data presented in the case studies were taken from various locations in the state of Gujarat, India.

The model presented in this paper is generic for application of selection of optimal air pollution control strategies. The model presented has following salient features:

- Model considers multiple pollutants emitted from multiple sources. It considers multiple control devices to reduce emissions to desired level.

- Model considers environmental cost due to the emission of the pollutant into the atmosphere while optimizing total cost.

- $\quad$ The proposed model can be used for selecting best possible strategy by considering more alternatives like selecting one or more number of fields in an ESP, number of cells in a bag house, diameters of cyclone etc.

- The cost benefits associated with recovery of resources has been considered while selecting optimal air pollution control strategy.

\section{THEORIES}

\subsection{Development of Model}

The model considers the emission of multiple pollutants from each of the pollution source. It also considers multiple air pollution control equipments to control emissions from each source. These control equipments are associated with installation and operating cost. Each of these pollution control equipments has limited pollution reduction efficiency. Moreover, pollutants emitted into the atmosphere have their impact on human health. The model considers health cost due to emission of the pollutants. Total cost of control strategy to achieve desired reduction in emissions is a combination of installation, operating and health cost. Some of the pollution control equipment recovers useful resources. The benefit associated with such recovery is also considered while selecting the control strategy. The objective of the model is to minimize total cost while selecting control equipments over each pollutant source considered.

The indices, variables and parameters used in developing the model are presented prior to the model development.

\section{Indices}

$i$ pollution source.

$j$ control device.

$p$ multiple pollutant 


\section{Sets}

$i$ pollution source.

$j$ air pollution control devices.

$p$ multiple pollutants.

Variables

$X_{i j}=$ binary variable indicating whether control equipment $\mathrm{j}$

is selected on source $\mathrm{i}\left(\mathrm{X}_{\mathrm{ij}}=1\right)$ or not $\left(\mathrm{X}_{\mathrm{ij}}=0\right)$

Parameters

$C_{j}^{0} \quad$ Installation cost of control device $j$.

$C_{i j} \quad$ Operating cost of control $j$ when applied over source $i$.

$H C_{p} \quad$ Health cost of the pollutant $p$ in USD per $\mathrm{kg}$ of pollutants emitted.

$N \quad$ Number of air pollution control equipments $j$.

$B$ Budget available for the air pollution control system.

$L \quad$ Length of time horizon, for which, the control device is applied.

$D_{i} \quad$ Diameter of the stack attached to sources $i$ in $\mathrm{m}$.

$H_{i} \quad$ Height of the stack attached to sources $i$ in $\mathrm{m}$.

$V_{i} \quad$ Velocity of the gas through sources $i$ in $\mathrm{m} / \mathrm{s}$

$Q_{i} \quad$ Flow rate of the flue gas through sources $i$ in $\mathrm{m}^{3} / \mathrm{s}$.

$A_{i} \quad$ Cross section area of the stack attached to sources $i$ in $\mathrm{m}^{2}$.

$K_{i p} \quad$ Emission concentrations of pollutant $p$ from source $i$ in $\mathrm{mg} / \mathrm{m}^{3}$.

$R_{i j p} \quad$ Reduction capacities for control devices $j$ operated over source $i$ for pollutants $p$.

$K l_{i p} \quad$ Allowable emissions of pollutant $p$ from source $i$ in $\mathrm{mg} / \mathrm{m}^{3}$.

\subsection{Problem Formulation}

Evaluation of economic cost for control strategy is a crucial task. Two important components of economic cost are installation cost and operating cost. The cost incurred during erection and commission of the control equipments was considered as installation cost. Whereas cost associated with operation of the control equipments was considered as operational cost. Economic cost together with health cost becomes total cost. The objective of optimisation problem was to minimize total cost while selecting optimal control strategy.

\subsubsection{Operating Cost:}

Operating cost $=$

$$
\sum_{i} \sum_{j} C_{i j} X_{i j}\left[\left(1+i_{c o m}\right)^{n}-1 /\left(1+i_{c o m}\right) * i_{c o m}\right]
$$

The term $i_{\text {com }}$ indicates the combination of local interest rate and inflation effect, whereas $n$ is number of years of operations which control device, $j$ is operated over source $i$.

\subsubsection{Installation Cost}

The cost incurred during erection and commission of the control equipments was considered as installation cost. The installation cost includes cost of equipment, cost of erection and commissioning cost. It is well known that cost of the equipment depends on the capacity, material of construction and availability of the equipment.

The cost for setting up of control device $j$ attached to source $i$ is given by:

$$
\text { Installation cost }=\sum_{i} \sum_{j} C_{j}^{0} X_{i j}
$$

In the equations $1 \& 2$ for operating and installation cost, if a control option $j$ is not selected for application over any particular sources $i$ then $X_{i j}=0$ and becomes 1 when control equipment is selected.

Therefore, it is to be noted that operating and installation cost of the control equipment is taken into consideration only if a control option is selected for application over any particular sources. Otherwise, the installation and operating cost would be equal to zero and does not contribute to the total cost.

\subsubsection{Health Cost}

In the present work, quantification of health impact for air pollutants was considered using the impact pathway analysis methodology (Friedrich et al. 2001). The method found to be more appropriate for present study as the dispersion model used was suitable for particulate emissions dispersion. The methodology incorporated modelling of air pollutants from point and line sources. The dose response function (fDR) has been elaborated as $Y=\mathrm{fDR}(\mathrm{Z})$ which relates the quantity, $Z$ of a pollutant that affects a receptor (e.g. population) to the physical impact $Y$ on this receptor (e.g. incremental number of hospitalizations).

The health impact associated with emission of classical pollutant $p$ is $H C_{p}$. This was expressed as US dollar per unit amount of pollutant released into the atmosphere. The concentration of pollutant $p$ generated from source $i$ is $K_{i p}$. While, the concentration of the pollutant p emitted into the atmosphere through stack attached to source $i$ is $K 1_{i p}$. The pollutants are emitted through sources $i$ with flow rate $Q_{i}$. Time for which air pollution control equipment $j$ operates over source $i$ is $\left(L-T_{\text {inst }}\right)$.

Therefore, the health cost associated with emission of pollutants from the outlets of the air pollution control devices is:

$$
\text { Health cost }=\sum_{i} \sum_{p} H C_{p} K 1_{i p} Q_{i}\left(L-L_{\text {inst }}\right)
$$

\subsubsection{Cost of Material Recovered}

It has been observed that materials recovered using various air pollution control equipment may be a value added by product. For example, one of the general gaseous pollutants observed in pharmaceutical industries is hydrochloric acid fumes. This can be scrubbed using distilled water, which 
results in generation of weak hydrochloric acid (30-40\%). This is a by product and can be reused or sold so as to contribute to total profit. Similarly, in case of emission of particulate matter, particles emitted from a variety of sources can be raw materials, intermediates or finished products. Recovery of this particulate matter is beneficial and reduces the overall cost. Therefore, it becomes an important aspect to be considered along with other costs like installation cost, operating cost and health cost. In the present study, a generic function RMC has been proposed which relates benefit of recovery. Here, RMC can be visualised as a constant that gives cost in US dollars per unit quantity of material recovered.

Cost of material recovered $=$

$$
\sum_{i} \sum_{p} R M C\left(K_{i p}-K 1_{i p}\right) Q_{i}\left(L-T_{i n s t}\right)
$$

Objective function is to minimize the total cost which includes operating, installation and health cost.

Minimize

$$
\begin{aligned}
& {\left[\sum_{i} \sum_{j} C_{i j} X_{i j}\left(\left(1+i_{c o m}\right)^{n}-1 /\left(1+i_{c o m}\right) * i_{c o m}\right)+\sum_{i} \sum_{j} C_{j}^{0} X_{i j}+\sum_{i} \sum_{p} H C_{p} K 1_{i p} Q_{i}\left(L-T_{i n s t}\right)\right]-} \\
& {\left[\sum_{i} \sum_{p} R M C\left(K_{i p}-K 1_{i p}\right) Q_{i}\left(L-T_{i n s t}\right)\right]}
\end{aligned}
$$

\subsubsection{Constraints:}

1. The inlet concentrations of pollutant $p$ through the source $i,\left(K_{i p}\right)$ shall be minimized to allowed outlet emission concentrations $\left(K 1_{i p}\right)$. This in general is decided by the regulatory authority. However, each air pollution control equipment $j$ is associated with limited collection efficiency $\left(R_{i j p}\right)$ to remove pollutant $p$ generated from source $i$.

$$
K_{i p} * \prod_{j}\left(\left(1-R_{i j p} / 100\right) * X_{i j}\right) \leq K 1_{i p}
$$

2. When collection efficiency of the control devices are known a priory number of control equipments to be used can be obtained based on inlet pollutant concentrations. This information may be useful to impose a constraint so as to reduce the search space. Hence, the maximum number of control equipments to be used on the source $i$ shall not exceed $N$.

$$
\sum_{j} X_{i j} \leq N
$$

3. Non negativity constraints.

$$
\mathrm{L} \geq 0
$$

4. It is important to consider local regulatory requirements while developing the model. Some regulatory authorities enforce installation of minimum one control equipment on each of the emission source. The constraint given in equation 9 ensures that for each source $i$ at least one control equipment $j$ installed. This constraint can be relaxed without affecting the performance of the model if no such regulatory requirements exist.

$$
\sum_{j} X_{i j} \geq 1
$$

5. The objective function, which includes installation cost, operating cost and health cost along with benefits of material recovered, shall not exceed the allotted budget. This constraint also can be relaxed without affecting the performance of the model if there is no budget limitation.

$\left[\sum_{i} \sum_{j} C_{i j} X_{i j}\left(\left(1+i_{c o m}\right)^{n}-1 /\left(1+i_{c o m}\right) * i_{c o m}\right)+\sum_{i} \sum_{j} C_{j}^{0} X_{i j}+\sum_{i} \sum_{p} H C_{p} K 1_{i p} Q_{i}\left(L-T_{i n s t}\right)\right]-$

$\left[\sum_{i} \sum_{p} R M C\left(K_{i p}-K 1_{i p}\right) Q_{i}\left(L-T_{i n s t}\right)\right]$ 


\section{MIXED INTEGER NON LINEAR PROGRAMMING SOLUTION}

The objective function indicated in equation 1 minimizes total cost subjected to constraints given in equations 6 through 10. This mixed integer non linear programme can be solved using suitable commercial software. In the present work, General Algebraic Modelling System (GAMS) has been used for simulation (Brook et al. 1992). The detailed program starts with definition of indices, sets, parameters, variables, tables and equations in the required syntax. The software then compiles the model developed using Discrete and Continuous optimizer program (DICOPT) for solving MINLP problem.

\section{CASE STUDIES}

The proposed model can be used for selection of optimal air pollution control strategy. The model incorporates multiple sources, pollutants and variety of control equipments. This generic model minimizes total cost including economic cost and environmental cost. Moreover, the model also has a provision to incorporate benefits due to recovery of useful materials wherever it is applicable.

The efficacy of the proposed model has been demonstrated by considering case studies a) A scenario consists of more number of sources, considering economic cost and environmental cost along with the cost associated with recovery of useful materials. b) A scenario with a limited number of sources considering economic and environmental cost. c) A scenario where recovery of material has no significant contribution.
It is a well known fact that inhalation of particles smaller than $2.5 \mu m$ (PM2.5) and $10 \mu m$ (PM10) are associated with a range of respiratory and cardiovascular diseases. Production of cement with dry process is potential in emission of such particulate matter. Moreover in cement plants stationary emission sources have much variety in terms of type of material emits and its cost. Therefore, a commercially operated cement plant has been taken into consideration for case study. Similarly, another potential air polluting industry is coal based thermal power plants hence a typical power plant is also taken into consideration.

\subsection{A Typical Cement Plant}

A typical Portland cement manufacturing unit using dry process has been considered for the study. The capacity of the cement plant was known prior to application of the model. Limestone with other raw materials is crushed in crushers. The roughly crushed material is then passed through raw mills where it is sized, dried and finely ground. This raw mix is then fed in to pre-heater and pre-calciner where decarbonisation of raw material takes place before the introduction in to a rotary kiln. Coal is fired within rotary kiln after being ground in coal mill. Within Kiln, raw mix is converted to clinker at the reaction temperature of about $1400^{\circ} \mathrm{C}$. The kiln outlet temperature is brought down to $100^{\circ}$ $\mathrm{C}-200^{\circ} \mathrm{C}$ by means of a cooler. The mixture is then finally ground in cement mill, which gives the final product. The present study considered point sources for cement production and classical pollutants $\mathrm{PM}, \mathrm{SO}_{2}, \mathrm{NO}_{x}$. The air pollution control equipments considered for application over these sources is an electrostatic precipitator, bag filter and cyclone separator.

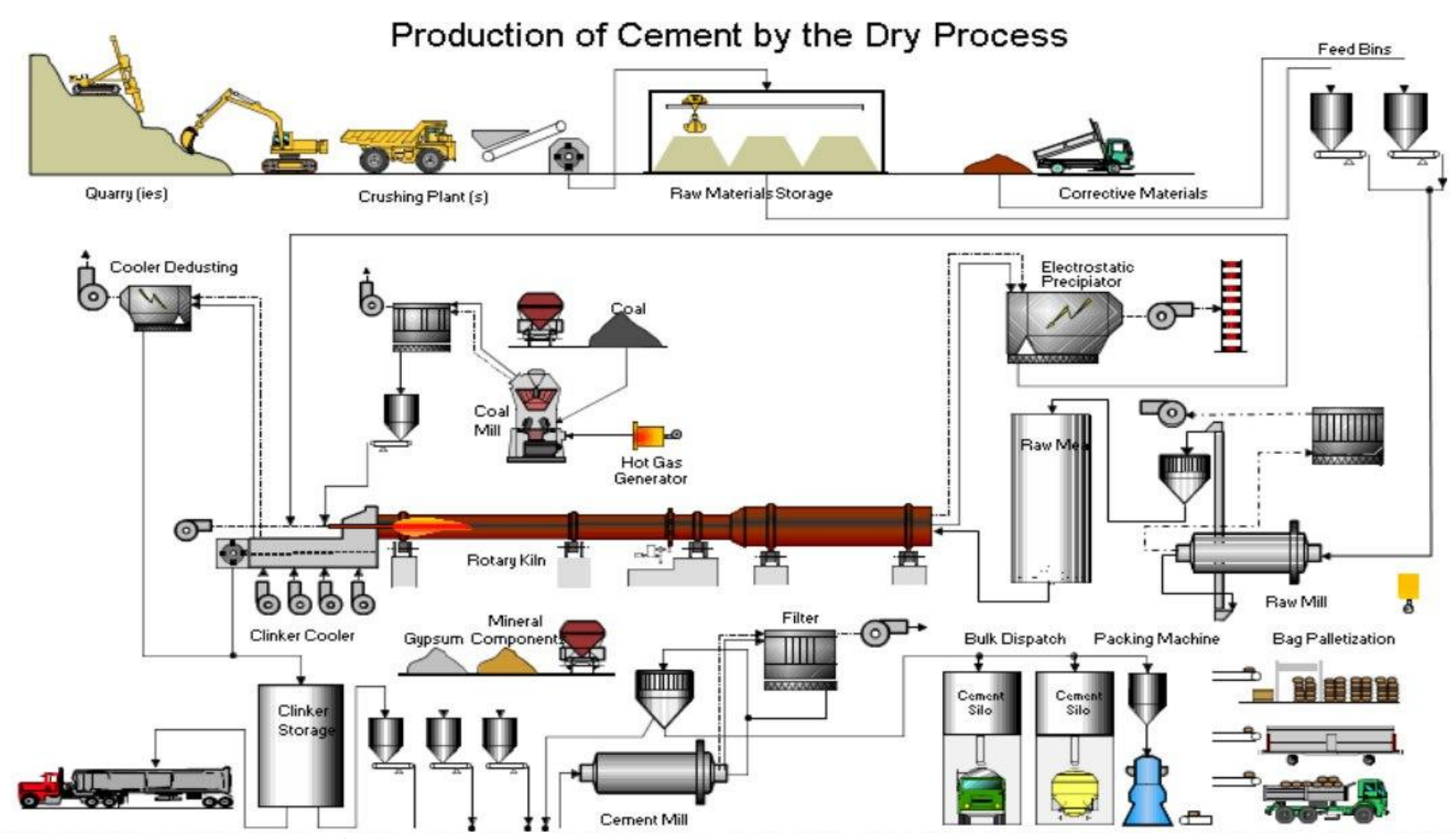

Fig 1: Process Flow sheet of cement production through dry process 
The actual data has been collected from four commercially operated cement plants for three seasons in a year for four years. The data collected include dimensions of stationary sources like diameter and height of stacks. The pollutants concentration and flow rates from the stacks are monitored using 'Vayubodhan' make stack monitoring kit and 'Vayubodhan' make velocity meter 'VVM1' respectively. The cost associated with commissioning and operation of the control equipments was also collected. The data presented in this paper are representative results obtained from these plants.

Two scenarios have been considered for simulation study. Scenario - I is a simplified version of the total problem where only installation, operating and health cost was considered. This scenario considers that crusted lime stone was readily available at the plant location to produce clinker as final product. Whereas the Scenario-II also incorporates the sources related to crushing and cement mill. Special emphasis was given to benefits obtained due to recovery of material using pollution control equipment in Scenario-II.

Three pollution control devices namely bag filter, electrostatic precipitator and cyclone separator were considered. The installation and operating cost of these devises are presented in Table 1 and Table 2 respectively. For representative calculation of operational cost over the period of lifetime local interest rate of $10 \%$ and inflation of 0.07 was considered. Emission concentration from each source depends on the type of process involved and production capacity of the plant. Typical data considered for simulation purpose regarding the source dimensions and emission concentrations are presented in Table 3 and Table 4 respectively. Details of the health cost due to pollutant emissions as reported in the literature is presented in Table 5. The reduction capabilities for each one of the air pollution control devices was evaluated actually covering three seasons in a year for four years. The average values of such reduction capabilities of control equipments are mentioned in Table 6.

Table 1: Installation cost for the control devices

\begin{tabular}{|l|l|}
\hline Control Devices & Installation cost $($ Co $)$ millions (USD) \\
\hline Bag filter & 0.34 \\
\hline ESP & 0.4 \\
\hline Cyclone & 0.3 \\
\hline
\end{tabular}

Table 2: Operating costs in Millions USD for control devices per annum when attached to each one of the source

\begin{tabular}{|l|l|l|l|}
\hline \multirow{2}{*}{ Sources } & \multicolumn{3}{|l|}{ Control Devices } \\
\cline { 2 - 4 } & Bag filter & ESP & Cyclone \\
\hline Crusher & 0.088 & 0.104 & 0.062 \\
\hline Raw Mill & 0.802 & 0.776 & 0.722 \\
\hline Coal Mill & 0.36 & 0.36 & 0.32 \\
\hline Cooler & 1.118 & 1.084 & 1.012 \\
\hline Cement mill & 0.398 & 0.392 & 0.354 \\
\hline
\end{tabular}

Table 3: Dimensions \& other details of sources

\begin{tabular}{|l|l|l|l|l|l|}
\hline Stack attached to & $\begin{array}{l}\text { Diameter } \\
(\mathbf{m})\end{array}$ & $\begin{array}{l}\text { Height } \\
(\mathbf{m})\end{array}$ & $\begin{array}{l}\text { Velocity } \\
(\mathbf{m} / \mathbf{s})\end{array}$ & $\begin{array}{l}\text { Area } \\
\left(\mathbf{m}^{\mathbf{2}}\right)\end{array}$ & $\begin{array}{l}\text { Flow rate } \\
\left(\mathbf{m}^{3} / \mathbf{s}\right)\end{array}$ \\
\hline Crusher & 1.5 & 33 & 11.21 & 1.766 & 19.79 \\
\hline Raw Mill & 4.6 & 135 & 15.32 & 16.61 & 254.74 \\
\hline Coal Mill & 2.53 & 60 & 21.73 & 5.02 & 109.18 \\
\hline Cooler & 4.25 & 60 & 25.16 & 14.17 & 356.74 \\
\hline Cement mill & 3.5 & 53 & 12.18 & 9.61 & 117.12 \\
\hline
\end{tabular}

Table 4: Concentrations of the pollutants at the inlet of the control device in $\mathrm{mg} / \mathrm{m} .3$

\begin{tabular}{|l|l|l|l|}
\hline \multirow{2}{*}{ Emission Sources } & \multicolumn{4}{|l|}{ Pollutants concentration in $\mathbf{~ m g / \mathbf { m } ^ { \mathbf { 3 } }}$} \\
\cline { 2 - 4 } & $\mathbf{P M}$ & $\mathbf{S O}_{\mathbf{2}}$ & $\mathbf{N O}_{\mathbf{X}}$ \\
\hline Crusher & 22000 & 90 & 90 \\
\hline Raw mill & 20000 & 90 & 90 \\
\hline Coal mill & 18000 & 100 & 100 \\
\hline Cooler & 18000 & 100 & 100 \\
\hline Cement mill & 25000 & 90 & 90 \\
\hline
\end{tabular}

Table 5: Details of the health cost due to pollutant emission as reported in the literature (Friedrich et al. 2001).

\begin{tabular}{|l|l|}
\hline Type of pollutants & Health cost ( USD per Kg of pollutant) \\
\hline $\mathrm{PM}$ & 0.09 \\
\hline $\mathrm{SO}_{2}$ & 0.063 \\
\hline $\mathrm{NOx}$ & 0.08 \\
\hline
\end{tabular}


Table 6: Reduction efficiencies of control devices

\begin{tabular}{|l|l|l|l|}
\hline \multirow{2}{*}{ Source and control devices } & \multicolumn{2}{l|}{$\begin{array}{l}\text { Reduction capacities of the control devices in \% for the } \\
\text { given pollutants }\end{array}$} \\
\cline { 2 - 4 } & PM & $\mathbf{S O}_{\mathbf{2}}$ & $\mathbf{N O}_{\mathbf{X}}$ \\
\hline Bag filter applied over crusher & 75 & 30 & 30 \\
\hline ESP applied over crusher & 98 & 30 & 30 \\
\hline Cyclone applied over crusher & 50 & 20 & 20 \\
\hline Bag filter applied over raw mill & 75 & 30 & 30 \\
\hline ESP applied over raw mill & 98 & 30 & 30 \\
\hline Cyclone applied over raw mill & 50 & 20 & 20 \\
\hline Bag filter applied over coal mill & 75 & 30 & 30 \\
\hline ESP applied over coal mill & 98 & 30 & 30 \\
\hline Cyclone applied over coal mill & 50 & 20 & 20 \\
\hline Bag filter applied over cooler & 75 & 30 & 30 \\
\hline ESP applied over cooler & 98 & 30 & 30 \\
\hline Cyclone applied over cooler & 55 & 20 & 20 \\
\hline Bag filter applied over cement mill & 75 & 30 & 30 \\
\hline ESP applied over cement mill & 98 & 30 & 30 \\
\hline Cyclone applied over cement mill & 55 & 20 & 20 \\
\hline
\end{tabular}

\subsubsection{Result and Discussion of Scenario - I (without benefits of material recovered):}

The MINLP problem has been solved, using commercial solver GAMS and the results obtained are presented in Table 7. Operating cost evaluated for Scenario-I, is presented in Figure 2 and Figure 3 illustrated installation and health cost. The total cost incurred for the restricted case is presented in Figure 4.

From Figure $2 \& 3$ and Table 7, it can be observed that as emission norms become stringent all the equipments are used to reduce emissions to required levels. This scenario leads to high installation and operating cost. On the other hand as expected, the health cost becomes least when the emission norms are stringent. As the emission, norms relaxed beyond $80 \mathrm{mg} / \mathrm{m}^{3}$ for PM the installation cost changes abruptly. This can be attributed to change in the selection of control equipments. Similar trend can be observed when the emission norms relaxed beyond $105 \mathrm{mg} / \mathrm{m}^{3}$. From Figure 4, it can be noted that there exists a minimum for the total cost indicating the possibility of selecting optimal air pollution control strategy. This scenario was observed at particulate emission of $240 \mathrm{mg} / \mathrm{m}^{3}, \mathrm{SO}_{2}$ and $\mathrm{NO}_{\mathrm{X}}$ concentrations of $100 \mathrm{mg} / \mathrm{m}^{3}$. The optimal strategy obtained suggested application of ESP and Bag filter as control devices on raw mill, coal mill and cooler.

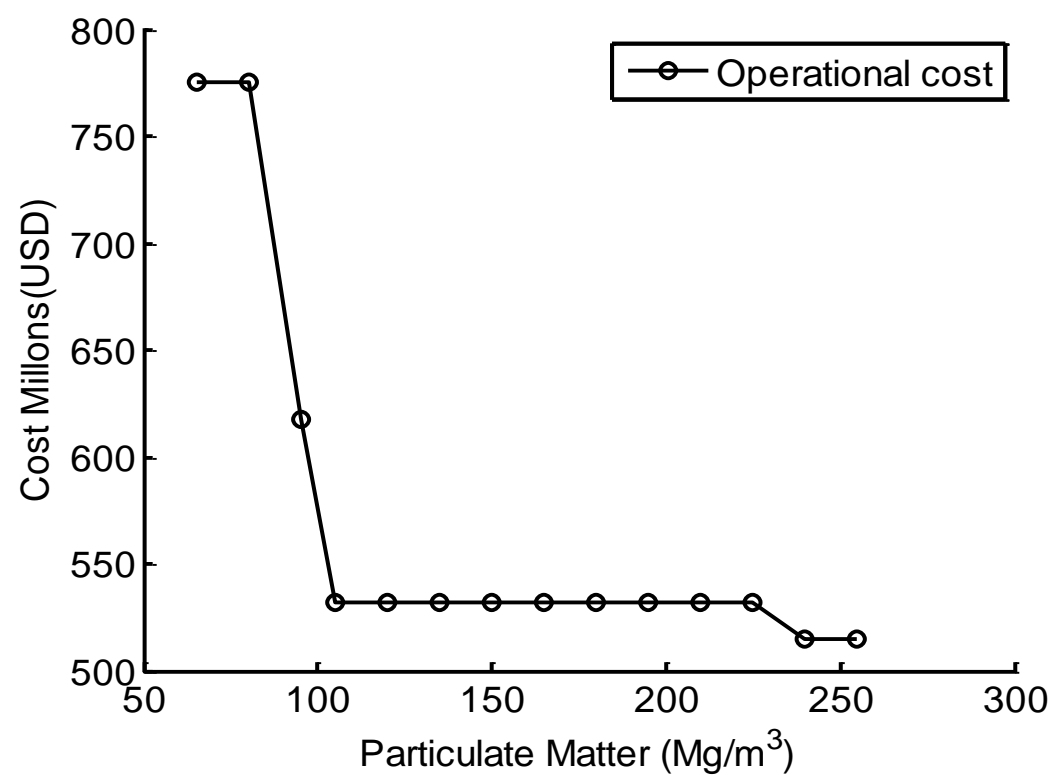

Fig 2: Operating cost of control equipment as a function of emission norms for scenario-I. 


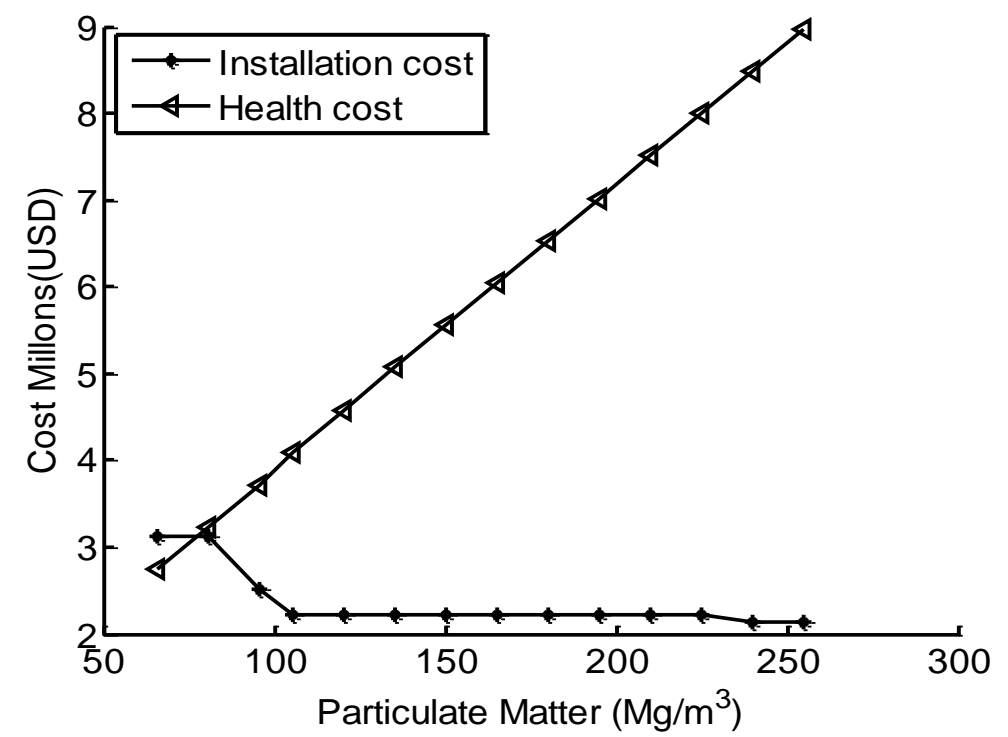

Fig 3: Installation \& Health cost of control equipment as a function of emission norms for scenario-I

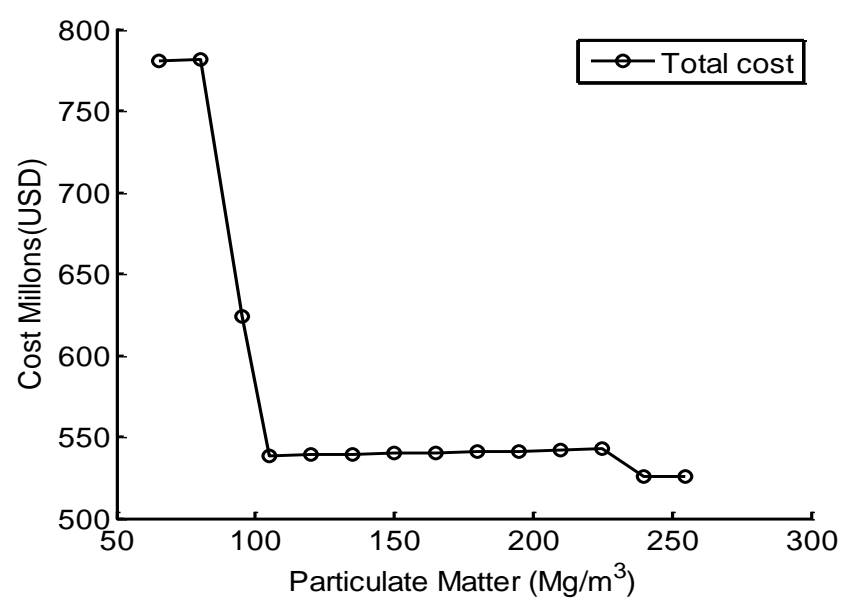

Fig 4: Total cost as a function of emission norms for scenario-I.

Table 7: Optimal selection of air pollution control equipment with changing outlet emission norms and constant operating years

\begin{tabular}{|c|c|c|c|c|c|c|}
\hline \multirow[t]{2}{*}{ Sources } & \multicolumn{3}{|c|}{$\begin{array}{l}\text { Outlet pollutant norms in } \\
\mathrm{mg} / \mathrm{m}^{3}\end{array}$} & \multicolumn{3}{|c|}{ Control Devices } \\
\hline & PM & $\mathrm{SO}_{2}$ & $\mathbf{N O}_{\mathbf{x}}$ & $\begin{array}{l}\text { Bag } \\
\text { filter }\end{array}$ & ESP & cyclone \\
\hline Raw mill & 65 & 40 & 40 & 1 & 1 & 1 \\
\hline Coal mill & 65 & 40 & 40 & 1 & 1 & 1 \\
\hline Cooler & 65 & 40 & 40 & 1 & 1 & 1 \\
\hline Raw mill & 95 & 50 & 50 & 1 & 1 & 1 \\
\hline Coal mill & 95 & 50 & 50 & 1 & 1 & $\mathrm{X}$ \\
\hline Cooler & 95 & 50 & 50 & 1 & 1 & $\mathrm{X}$ \\
\hline Raw mill & 105 & 55 & 55 & 1 & 1 & $\mathrm{X}$ \\
\hline Coal mill & 105 & 55 & 55 & 1 & 1 & $\mathrm{X}$ \\
\hline Cooler & 105 & 55 & 55 & 1 & 1 & $\mathrm{X}$ \\
\hline Raw mill & 120 & 60 & 60 & 1 & 1 & $\mathrm{X}$ \\
\hline Coal mill & 120 & 60 & 60 & 1 & 1 & $\mathrm{X}$ \\
\hline Cooler & 120 & 60 & 60 & 1 & 1 & $\mathrm{X}$ \\
\hline
\end{tabular}




\begin{tabular}{|l|l|l|l|l|l|l|}
\hline Raw mill & 150 & 70 & 70 & 1 & 1 & X \\
\hline Coal mill & 150 & 70 & 70 & 1 & 1 & X \\
\hline Cooler & 150 & 70 & 70 & 1 & 1 & X \\
\hline Raw mill & 180 & 80 & 80 & 1 & 1 & X \\
\hline Coal mill & 180 & 80 & 80 & 1 & 1 & X \\
\hline Cooler & 180 & 80 & 80 & 1 & 1 & X \\
\hline Raw mill & 225 & 95 & 95 & 1 & 1 & X \\
\hline Coal mill & 225 & 95 & 95 & 1 & 1 & X \\
\hline Cooler & 225 & 95 & 95 & 1 & 1 & X \\
\hline Raw mill & 240 & 100 & 100 & 1 & 1 & X \\
\hline Coal mill & 240 & 100 & 100 & X & 1 & 1 \\
\hline Cooler & 240 & 100 & 100 & X & 1 & 1 \\
\hline Raw mill & 255 & 105 & 105 & 1 & 1 & X \\
\hline Coal mill & 255 & 105 & 105 & X & 1 & 1 \\
\hline Cooler & 255 & 105 & 105 & X & 1 & 1 \\
\hline
\end{tabular}

\subsubsection{Result and Discussion Scenario - II (Including Benefits of Material Recovered):}

In scenario-II, the cost of the material recovered during reduction of emission by control equipment has been considered. The typical cost for the raw material, intermediates and the final products are taken in to consideration while calculating the total cost of the selection options. The cost of the material recovered by the control equipment attached to crusher, raw mill, coal mill and cement mill operation is given in Table 8 .

Table 8: Cost of the material recovered from various sources in USD per $\mathrm{Kg}$ of the material recovered.

\begin{tabular}{|l|l|}
\hline Type of source & Cost \\
\hline Crusher & 0.005 \\
\hline Raw Mill & 0.0056 \\
\hline Coal mill & 0.06 \\
\hline Cement mill & 0.04 \\
\hline
\end{tabular}

The simulation results obtained from MINLP problem using GAMS solver for scenario-II are presented in Table 9 and Figures 5, $6 \& 7$. From Figure $5 \& 6$, it can be observed that the installation cost, operating cost and health cost follow a similar trend as discussed for the restricted case. However, the installation and operating cost are relatively high compared to the previous scenario as the number of sources is more.

The benefit of recovering resources using pollution control devises is presented in Figure 7. The profit obtained by recovering resources (raw material, products) appears to be proportional to the material recovered. The profit obtained by recovering material is approximately 40 times more than cumulative cost incurred by installation, operating and health cost for the case under consideration. From Figure 7 it also can be observed that there exists a maximum for the total cost at outlet norms of PM at 95 $\mathrm{mg} / \mathrm{m}^{3}$. This is indicating significant effect of recovery on the optimal selection of air pollution control strategy. Minor changes in the installation and operating cost has been found no significant effect on the selection of equipment but the total cost changes according to these variations.

Table 9: Optimal selection of air pollution control equipments with changing outlet emission norms and constant operating years

\begin{tabular}{|l|l|l|l|l|l|l|}
\hline Sources & \multicolumn{2}{l}{$\begin{array}{l}\text { Outlet } \\
\text { mg/m }\end{array}$} & pollutant norms in & \multicolumn{2}{l|}{ Control Devices } \\
\cline { 2 - 7 } & PM & SO $_{2}$ & NOx & $\begin{array}{l}\text { Bag } \\
\text { filter }\end{array}$ & ESP & Cyclone \\
\hline Crusher & 65 & 40 & 40 & 1 & 1 & 1 \\
\hline Raw mill & 65 & 40 & 40 & 1 & 1 & 1 \\
\hline Coal mill & 65 & 40 & 40 & 1 & 1 & 1 \\
\hline Cooler & 65 & 40 & 40 & 1 & 1 & 1 \\
\hline Cement Mill & 65 & 40 & 40 & 1 & 1 & 1 \\
\hline
\end{tabular}




\begin{tabular}{|c|c|c|c|c|c|c|}
\hline Crusher & 110 & 49 & 49 & 1 & 1 & $X$ \\
\hline Raw mill & 110 & 49 & 49 & 1 & 1 & $\mathrm{X}$ \\
\hline Coal mill & 110 & 49 & 49 & 1 & 1 & $\mathrm{X}$ \\
\hline Cooler & 110 & 49 & 49 & 1 & 1 & $\mathrm{X}$ \\
\hline Cement Mill & 110 & 49 & 49 & 1 & 1 & 1 \\
\hline Crusher & 125 & 41 & 41 & 1 & 1 & $\mathrm{X}$ \\
\hline Raw mill & 125 & 41 & 41 & 1 & 1 & $\mathrm{X}$ \\
\hline Coal mill & 125 & 41 & 41 & 1 & 1 & $\mathrm{X}$ \\
\hline Cooler & 125 & 41 & 41 & 1 & 1 & $\mathrm{X}$ \\
\hline Cement Mill & 125 & 41 & 41 & 1 & 1 & $\mathrm{X}$ \\
\hline Crusher & 140 & 54 & 54 & 1 & 1 & $\mathrm{X}$ \\
\hline Raw mill & 140 & 54 & 54 & 1 & 1 & $\mathrm{X}$ \\
\hline Coal mill & 140 & 54 & 54 & 1 & 1 & $\mathrm{X}$ \\
\hline Cooler & 140 & 54 & 54 & 1 & 1 & $\mathrm{X}$ \\
\hline Cement Mill & 140 & 54 & 54 & 1 & 1 & $\mathrm{X}$ \\
\hline Crusher & 155 & 57 & 57 & 1 & 1 & $\mathrm{X}$ \\
\hline Raw mill & 155 & 57 & 57 & 1 & 1 & $\mathrm{X}$ \\
\hline Coal mill & 155 & 57 & 57 & 1 & 1 & $\mathrm{X}$ \\
\hline Cooler & 155 & 57 & 57 & 1 & 1 & $\mathrm{X}$ \\
\hline Cement Mill & 155 & 57 & 57 & 1 & 1 & $\mathrm{X}$ \\
\hline Crusher & 200 & 66 & 66 & 1 & 1 & $\mathrm{X}$ \\
\hline Raw mill & 200 & 66 & 66 & 1 & 1 & $\mathrm{X}$ \\
\hline Coal mill & 200 & 66 & 66 & 1 & 1 & $\mathrm{X}$ \\
\hline Cooler & 200 & 66 & 66 & 1 & 1 & $\mathrm{X}$ \\
\hline Cement Mill & 200 & 66 & 66 & 1 & 1 & $\mathrm{X}$ \\
\hline Crusher & 225 & 71 & 71 & 1 & 1 & $\mathrm{X}$ \\
\hline Raw mill & 225 & 71 & 71 & 1 & 1 & $\mathrm{X}$ \\
\hline Coal mill & 225 & 71 & 71 & 1 & 1 & $\mathrm{X}$ \\
\hline Cooler & 225 & 71 & 71 & 1 & 1 & $\mathrm{X}$ \\
\hline Cement Mill & 225 & 71 & 71 & 1 & 1 & $\mathrm{X}$ \\
\hline Crusher & 250 & 74 & 74 & 1 & 1 & $\mathrm{X}$ \\
\hline Raw mill & 250 & 74 & 74 & 1 & 1 & $\mathrm{X}$ \\
\hline Coal mill & 250 & 74 & 74 & $\mathrm{X}$ & 1 & 1 \\
\hline Cooler & 250 & 74 & 74 & $\mathrm{X}$ & 1 & 1 \\
\hline Cement Mill & 250 & 74 & 74 & 1 & 1 & $\mathrm{X}$ \\
\hline Crusher & 275 & 77 & 77 & 1 & 1 & $\mathrm{X}$ \\
\hline Raw mill & 275 & 77 & 77 & $\mathrm{X}$ & 1 & 1 \\
\hline Coal mill & 275 & 77 & 77 & $\mathrm{X}$ & 1 & 1 \\
\hline Cooler & 275 & 77 & 77 & $\mathrm{X}$ & 1 & 1 \\
\hline Cement Mill & 275 & 77 & 77 & $\mathrm{X}$ & 1 & $\mathrm{X}$ \\
\hline Crusher & 300 & 80 & 80 & $\mathrm{X}$ & 1 & 1 \\
\hline Raw mill & 300 & 80 & 80 & $\mathrm{X}$ & 1 & 1 \\
\hline Coal mill & 300 & 80 & 80 & $\mathrm{X}$ & 1 & 1 \\
\hline Cooler & 300 & 80 & 80 & $\mathrm{X}$ & 1 & 1 \\
\hline Cement Mill & 300 & 80 & 80 & $\mathrm{X}$ & 1 & $\mathrm{X}$ \\
\hline
\end{tabular}




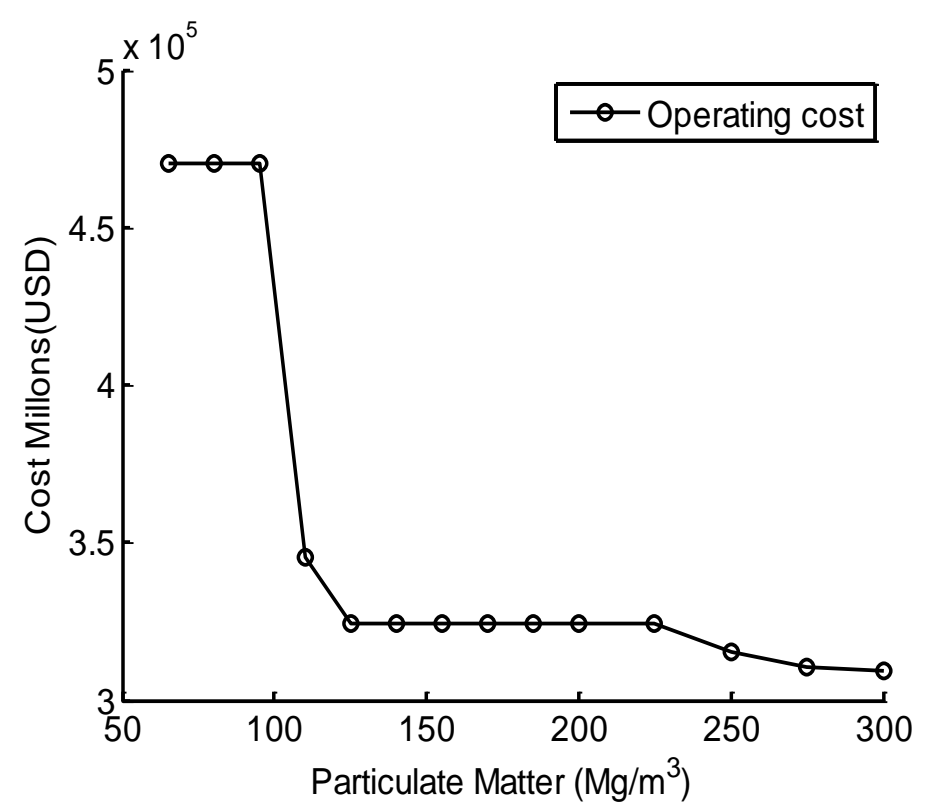

Fig 5: Operating cost of control equipment as a function of emission norms for scenario-II.

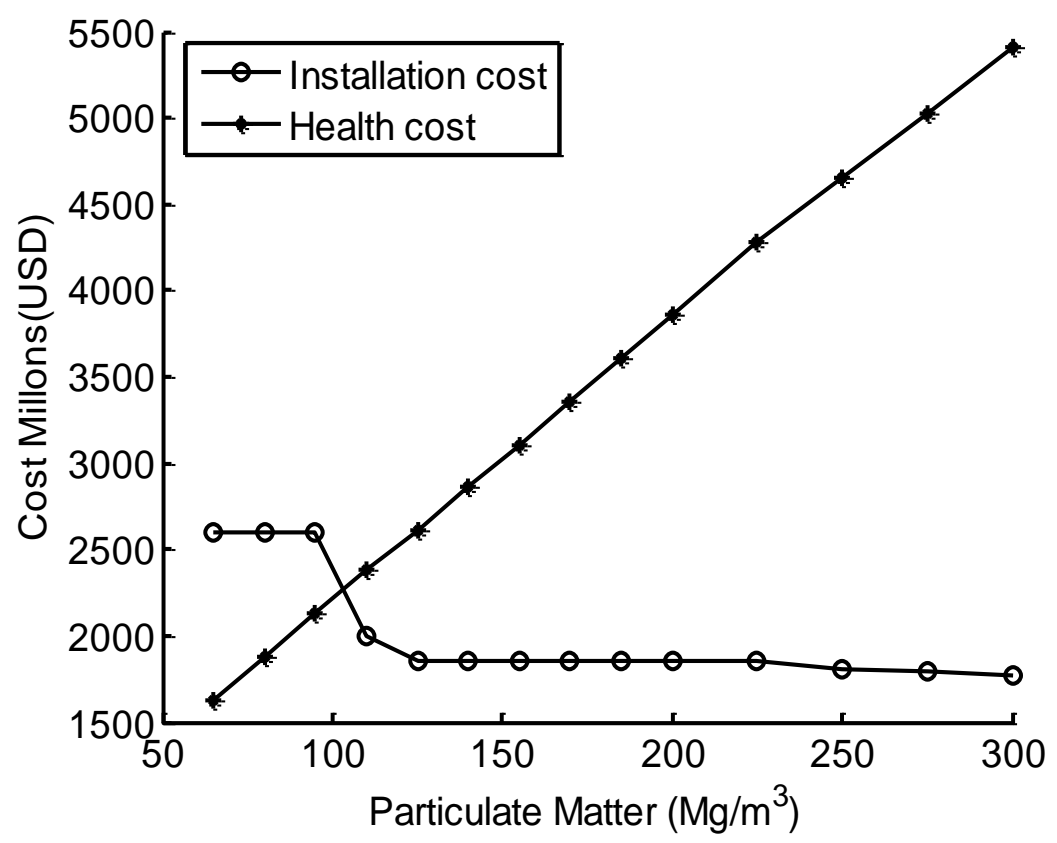

Fig 6: Installation cost of control equipment as a function of emission norms for scenario-II. 


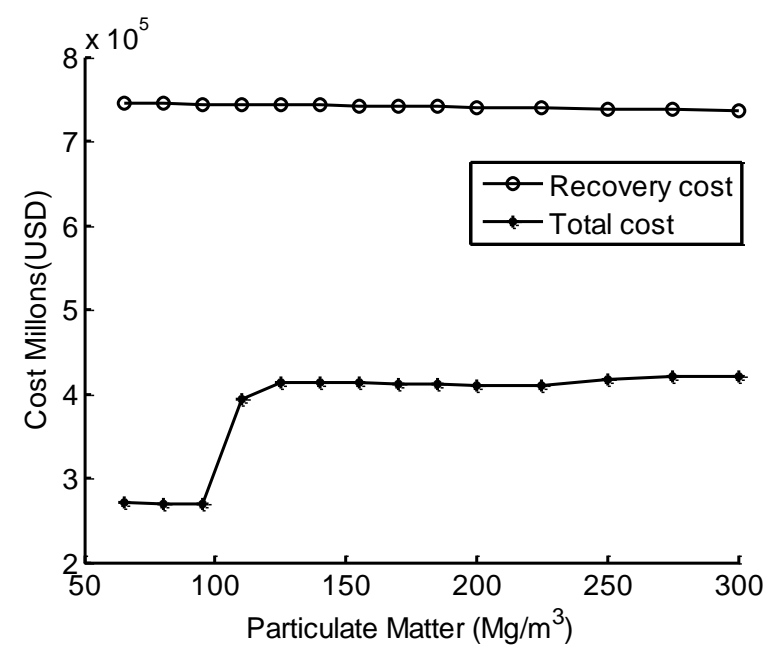

Fig 7: Recovery and total cost of control equipment as a function of emission norms for scenario-II.

\subsection{Case Study of a Typical Thermal Power Plant}

A typical steam/thermal power plant has been considered for the study. In the boiler, the pulverized lignite is fired to generate steam. The burning of lignite creates flue gas with classical pollutants as $\mathrm{PM}, \mathrm{SO}_{2}, \mathrm{NO}_{\mathrm{x}}$ and ash. Heat energy of flue gas is utilized by heating the air and water in the second pass of the boiler, by means or air pre-heater and economizer. Air pollution control measures are employed for collection of fly ash from the flue gases before emitted in to the atmosphere.

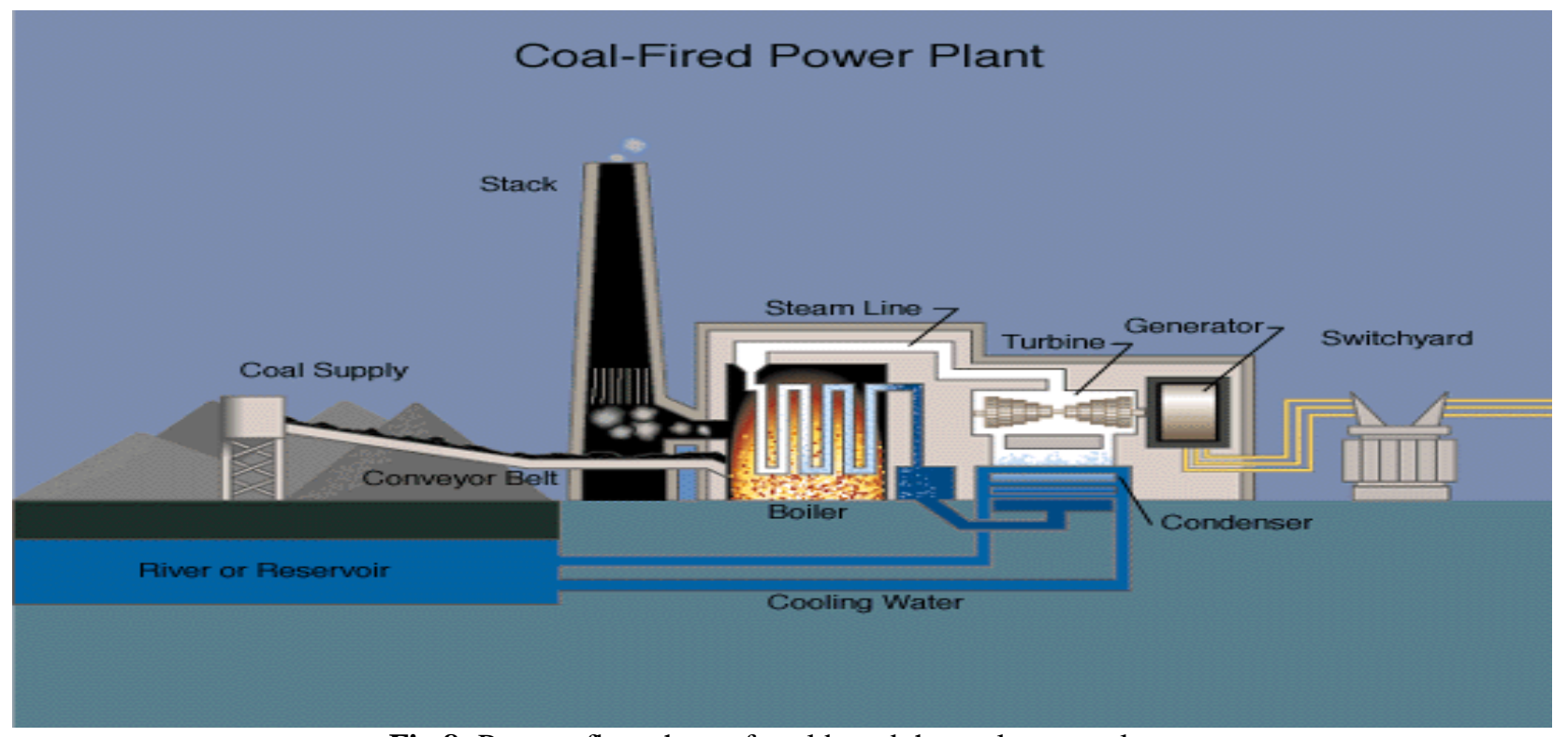

Fig 8: Process flow sheet of coal based thermal power plant.

The air pollution control equipments considered being applied over these sources are an electrostatic precipitator, bag filter and cyclone separator. To make the problem more realistic actual data of two commercially operated thermal power plants has been collected trice a year for two years. The data collected include dimensions of the stack and flow rates for evaluating the total load of the pollutant emitted. The pollutant concentration and flow rates from the stacks are monitored using 'Vayubodhan' make stack monitoring kit and 'Vayubodhan' make velocity meter 'VVM1' respectively. The cost associated with commissioning and operation of the control equipments was also collected. The data presented in this paper are representative results obtained from plants.

The installation and operating cost of the pollution control devises considered for the present study are presented in Table 10 and Table 11 respectively. Emission concentrations from each source depend on the process operation involved and the production capacity of the plant. Typical data considered for simulation purpose regarding the source dimensions and emission concentrations are presented in Table 12 and Table 13 respectively. Details of the health cost due to pollutant emissions as reported in the literature are presented in Table 14. The reduction capabilities for each one of the air pollution control devices was evaluated for two commercially operated thermal power plants actually. The average reduction capabilities of these control equipments are mentioned in Table 15. 
Table 10: Installation cost for the control devices.

\begin{tabular}{|l|l|}
\hline Control Devices & Installation cost $($ Co $)$ millions (USD) \\
\hline ESP & 0.3 \\
\hline Bag- house & 0.28 \\
\hline High efficiency Cyclone & 0.2 \\
\hline
\end{tabular}

Table 11: Operating cost in millions (USD) for control devices per annum, when attached to each one of the source.

\begin{tabular}{|l|l|l|l|}
\hline \multirow{2}{*}{ Sources } & \multicolumn{3}{|l|}{ Control Devices } \\
\cline { 2 - 4 } & ESP & Bag- house & High efficiency Cyclone \\
\hline Boiler 1 & 0.19 & 0.15 & 0.13 \\
\hline Boiler 2 & 0.162 & 0.12 & 0.1 \\
\hline Boiler 3 & 0.2 & 0.18 & 0.14 \\
\hline
\end{tabular}

Table 12: Dimensions \& other details of sources used for flow rate calculation

\begin{tabular}{|l|l|l|l|l|l|}
\hline Stack attached to & $\begin{array}{l}\text { Diameter } \\
(\mathbf{m})\end{array}$ & $\begin{array}{l}\text { Height } \\
(\mathbf{m})\end{array}$ & $\begin{array}{l}\text { Velocity } \\
(\mathbf{m} / \mathbf{s})\end{array}$ & $\begin{array}{l}\text { Area } \\
\left(\mathbf{m}^{2}\right)\end{array}$ & $\begin{array}{l}\text { Flow rate } \\
\left(\mathbf{m}^{\mathbf{3}} / \mathbf{s}\right)\end{array}$ \\
\hline Boiler 1 & 5.2 & 150 & 24.5 & 21.4 & 520 \\
\hline Boiler 2 & 5.2 & 150 & 26.7 & 21.4 & 567 \\
\hline Boiler 3 & 5.2 & 150 & 30.1 & 21.4 & 639 \\
\hline
\end{tabular}

Table No.13: Concentrations of the pollutants at the inlet of the control device in $\mathrm{mg} / \mathrm{m} .3$

\begin{tabular}{|l|l|l|l|}
\hline \multirow{2}{*}{ Emission Sources } & \multicolumn{4}{|l|}{ Pollutants concentration in $\mathbf{~ m g / \mathbf { m } ^ { \mathbf { 3 } }}$} \\
\cline { 2 - 4 } & $\mathbf{P M}$ & $\mathbf{S O}_{\mathbf{2}}$ & $\mathbf{N O}_{\mathbf{X}}$ \\
\hline Boiler 1 & 20000 & 120 & 120 \\
\hline Boiler 2 & 18000 & 120 & 120 \\
\hline Boiler 3 & 25000 & 140 & 140 \\
\hline
\end{tabular}

Table 14: Details of health cost due to pollutant emission as reported in the literature (Friedrich et al. 2001)

\begin{tabular}{|l|l|}
\hline Type of pollutants & $\begin{array}{l}\text { Health cost } \\
\text { ( USD per Kg of pollutant) }\end{array}$ \\
\hline $\mathrm{PM}$ & 0.09 \\
\hline $\mathrm{SO}_{2}$ & 0.063 \\
\hline $\mathrm{NO}_{\mathrm{x}}$ & 0.08 \\
\hline
\end{tabular}

Table 15: Reduction efficiencies of control devices

\begin{tabular}{|l|l|l|l|}
\hline \multirow{2}{*}{ Source and control devices } & \multicolumn{2}{l|}{$\begin{array}{l}\text { Reduction capacities of the control devices in \% for the } \\
\text { given pollutants }\end{array}$} \\
\cline { 2 - 4 } & PM & $\mathbf{S O}_{\mathbf{2}}$ & $\mathbf{N O}_{\mathbf{X}}$ \\
\hline ESP applied over boiler 1 & 95 & 30 & 30 \\
\hline Bag house applied over boiler 1 & 90 & 25 & 25 \\
\hline Cyclone applied over boiler 1 & 80 & 20 & 20 \\
\hline ESP applied over boiler 2 & 95 & 30 & 30 \\
\hline Bag house applied over boiler 2 & 90 & 25 & 25 \\
\hline Cyclone applied over boiler 2 & 80 & 20 & 20 \\
\hline ESP applied over boiler 3 & 90 & 30 & 30 \\
\hline Bag house applied over boiler 3 & 88 & 25 & 25 \\
\hline Cyclone applied over boiler 3 & 78 & 20 & 20 \\
\hline
\end{tabular}

\subsubsection{Result and Discussion (Thermal Power Plant):}

The MINLP problem has been solved using commercial solver GAMS, and the results obtained are presented in Table 16. Operating cost, health cost and installation cost evaluated are presented in Figure 9. The total cost incurred is presented in Figure 10. From simulation results, it was observed that for the stringent emission norms, (below $70 \mathrm{mg} / \mathrm{m} 3 \mathrm{of} P M$ ) removal of the pollutants becomes infeasible even after applying all the control options in series. From Table 16, it can be observed that in the feasible region also when the norms are comparatively stringent all the control devices are selected. This scenario leads to high installation and operating cost as shown in Figure 7. It can be also observed from the Figure 7 that health cost goes high as the emission norms are relaxed as expected. However, as the emission norms relaxed beyond $100 \mathrm{mg} / \mathrm{m}^{3}$ for PM the installation cost changes abruptly. Similar trend can be observed when the emission norms relaxed beyond $300 \& 400 \mathrm{mg} / \mathrm{m}^{3}$. Similarly, operating cost decreases with an increase in emission norms beyond $100 \mathrm{mg} / \mathrm{m}^{3}$. This can be attributed to change in the selection of control 
equipments. From Figure 8, it can be noted that there exists a minimum for the total cost indicating the possibility of selecting optimal air pollution control strategy. This scenario is observed at particulate emission of $100 \mathrm{mg} / \mathrm{m}^{3}, \mathrm{SO}_{2}$ and $\mathrm{NO}_{\mathrm{X}}$ concentrations of $64 \mathrm{mg} / \mathrm{m}^{3}$.

Table 16: Optimal selection of air pollution control equipments with changing outlet emission norms and constant operating years

\begin{tabular}{|c|c|c|c|c|c|c|}
\hline \multirow[t]{2}{*}{ Sources } & \multicolumn{3}{|c|}{ 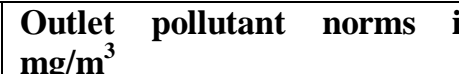 } & \multicolumn{3}{|c|}{ Control Devices } \\
\hline & PM & $\mathrm{SO}_{2}$ & $\mathrm{NO}_{\mathbf{x}}$ & ESP & $\begin{array}{l}\text { Bag } \\
\text { filter }\end{array}$ & $\begin{array}{l}\text { High Efficiency } \\
\text { cyclone }\end{array}$ \\
\hline Boiler-I & 70 & 60 & 60 & 1 & 1 & 1 \\
\hline Boiler-II & 70 & 60 & 60 & 1 & 1 & 1 \\
\hline Boiler-III & 70 & 60 & 60 & 1 & 1 & 1 \\
\hline Boiler-I & 85 & 62 & 62 & 1 & 1 & 1 \\
\hline Boiler-II & 85 & 62 & 62 & 1 & 1 & 1 \\
\hline Boiler-III & 85 & 62 & 62 & 1 & 1 & 1 \\
\hline Boiler-I & 100 & 64 & 64 & 1 & 1 & $\mathrm{X}$ \\
\hline Boiler-II & 100 & 64 & 64 & 1 & 1 & 1 \\
\hline Boiler-III & 100 & 64 & 64 & 1 & 1 & 1 \\
\hline Boiler-I & 150 & 66 & 66 & 1 & 1 & $\mathrm{X}$ \\
\hline Boiler-II & 150 & 66 & 66 & 1 & 1 & $\mathrm{X}$ \\
\hline Boiler-III & 150 & 66 & 66 & 1 & 1 & 1 \\
\hline Boiler-I & 200 & 68 & 68 & 1 & 1 & $\mathrm{X}$ \\
\hline Boiler-II & 200 & 68 & 68 & 1 & 1 & $\mathrm{X}$ \\
\hline Boiler-III & 200 & 68 & 68 & 1 & 1 & 1 \\
\hline Boiler-I & 250 & 70 & 70 & 1 & 1 & $\mathrm{X}$ \\
\hline Boiler-II & 250 & 70 & 70 & 1 & 1 & 1 \\
\hline Boiler-III & 250 & 70 & 70 & 1 & 1 & 1 \\
\hline Boiler-I & 300 & 72 & 72 & 1 & 1 & $\mathrm{X}$ \\
\hline Boiler-II & 300 & 72 & 72 & 1 & 1 & $\mathrm{X}$ \\
\hline Boiler-III & 300 & 72 & 72 & 1 & 1 & 1 \\
\hline Boiler-I & 350 & 74 & 74 & 1 & 1 & $\mathrm{X}$ \\
\hline Boiler-II & 350 & 74 & 74 & 1 & 1 & $\mathrm{X}$ \\
\hline Boiler-III & 350 & 74 & 74 & 1 & 1 & 1 \\
\hline Boiler-I & 400 & 76 & 76 & 1 & 1 & $\mathrm{X}$ \\
\hline Boiler-II & 400 & 76 & 76 & $\mathrm{X}$ & 1 & 1 \\
\hline Boiler-III & 400 & 76 & 76 & 1 & 1 & $\mathrm{X}$ \\
\hline Boiler-I & 450 & 78 & 78 & 1 & 1 & $\mathrm{X}$ \\
\hline Boiler-II & 450 & 78 & 78 & $\mathrm{X}$ & 1 & 1 \\
\hline Boiler-III & 450 & 78 & 78 & 1 & 1 & $\mathrm{X}$ \\
\hline Boiler-I & 500 & 80 & 80 & 1 & 1 & $\mathrm{X}$ \\
\hline Boiler-II & 500 & 80 & 80 & $\mathrm{X}$ & 1 & 1 \\
\hline Boiler-III & 500 & 80 & 80 & 1 & 1 & $\mathrm{X}$ \\
\hline
\end{tabular}

The optimal selection strategy for air pollution control devices has been evaluated for a typically operated thermal power plant. The model considered economical as well as environmental cost of the options available. 


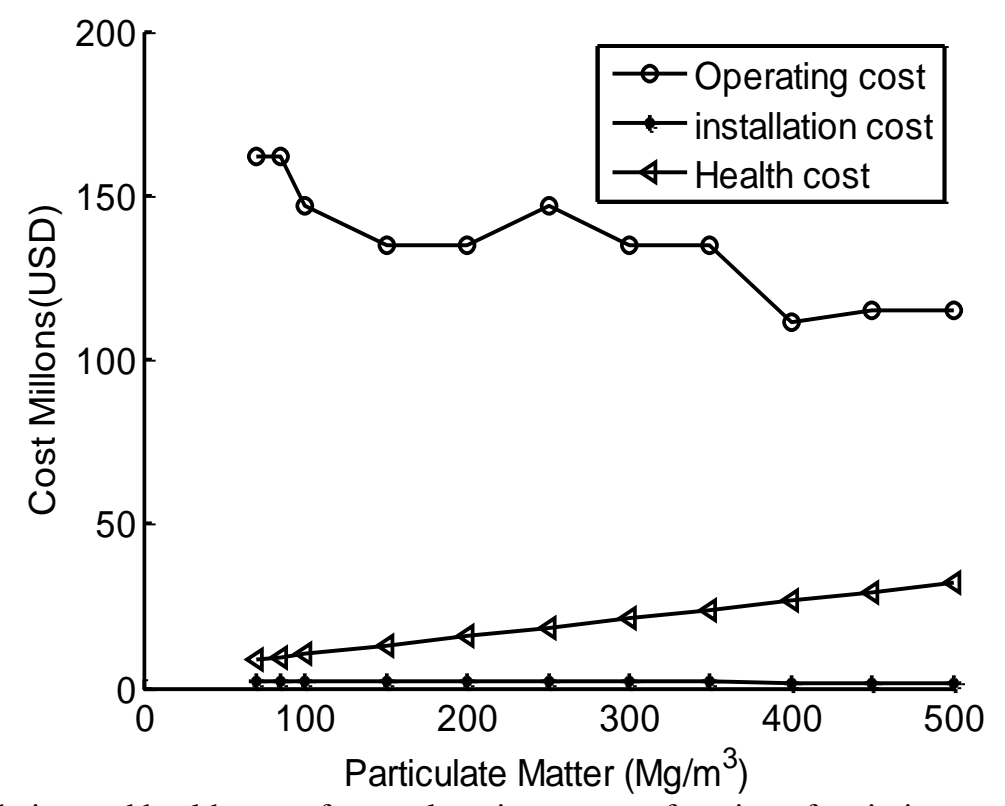

Fig 9: Operating, installation and health cost of control equipment as a function of emission norms for thermal power plant.

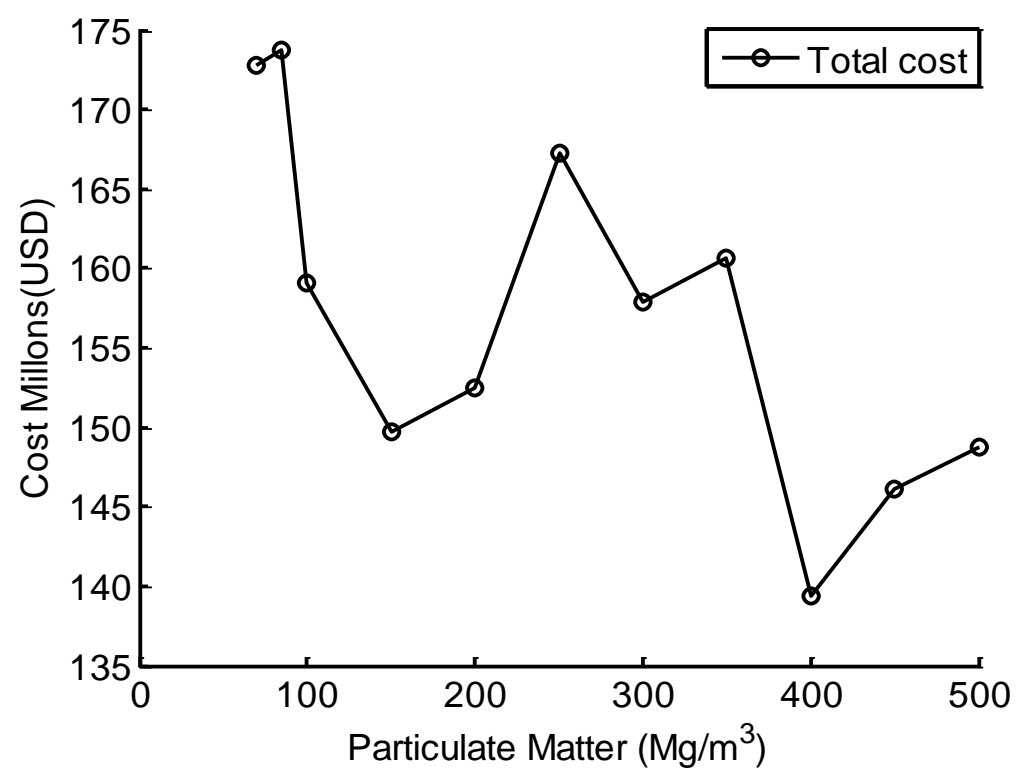

Fig 10: Total cost of control equipment as a function of emission norms for thermal power plant.

\section{CONCLUSION}

In the present study, a MINLP based optimisation model for selection of optimal air pollution control strategy has been formulated. The model incorporates health cost along with economical cost for optimal selection of various control options. It considers multiple emission sources, each one of them emitting multiple pollutants. Objective of the model was to minimize the total cost with reduction of pollutants to a prescribed level. The optimal selection strategy for air pollution control which includes operational, installation, health cost and profit through recovery has been presented for the given outlet pollution norms. The efficacy of the proposed model has been satisfactorily evaluated by considering simulation case studies of a typically operated cement plant and a thermal power plant.

\section{REFERENCES}

[1] Akbar, S., Kojima, M., Pandey, K., D., (2003). World Health Organization briefing note as part of the South Asia program on urban air quality management. UNDP/World Bank Energy Sector Management Assistance Programme (ESMAP).

[2] Azapagic, A., Clift, R., (1995). Life Cycle Assessment and Linear Programming Environmental Optimisation of Product System. Computers and Chemical Engineering. 19, S229-S234.

[3] Azapagic, A., Clift, R., (1999). The application of life cycle assessment to process optimization. Computers and Chemical Engineering. 23, 15091526. 
[4] Biegler, L., T., Grossmann, I., E.,(2004). Retrospective on optimization. Computers and Chemical Engineering. 28, 1169-1192.

[5] Brook, A., Kendrick , D., Meeraus, A. (1992) GAMS: A user's Guide. The scientific press series, Boyd \& Fraser publishing company, Danvers, Massachusetts.

[6] Carvalho, A., Matos, H., A., Gania, R., (2009). Design of batch operations: Systematic methodology for generation and analysis of sustainable alternatives, Computers and Chemical Engineering. doi:10.1016/j.compchemeng.2009.06.015

[7] Chandra, H., Kaushik, S., C., Chandra, A., (2009). Impact of Environmental cost on Economics of Thermal power plant. IE (I) journal-EN. 89, 14-19.

[8] Chen, Q., Feng, X.,(2005). A pollution reduction methodology in reactor design. Chemical Engg and processing. 44, $13-21$.

[9] Cora, M.G., Hung, Y.T., (2002). Controlling industrial particulate emissions: a practical overview of bag house technology. Environment Quality Manager.11, 53-64.

[10] Couvert, A., Charronb, I., Laplanchea, A., Renner, C., Patria, L., Requieme, B., (2006). Treatment of odorous sulphur compounds by chemical scrubbing with hydrogen peroxide-Application to a laboratory plant. Chemical Engineering Science. 61, $7240-7248$.

[11] Douglas, J., M., (1992). Process synthesis for waste minimization. Ind. Eng. Chem. Res. 31, 238-243.

[12] Filliger, P., Texier, V.P., Schneider, J., (1999). Health Costs due to Road Traffic-related: Air Pollution An impact assessment project of Austria, France and Switzerland. WHO Ministerial Conference for Environment and Health, London.

[13] Friedrich, R., Rabl, A., Spadaro, J. V., (2001). Quantifying the Costs of Air Pollution: the ExternE Project of the EC. Pollution Atmospherique. 77-104.

[14] Hossain, K., A., Khan, F., I., Hawboldt, K., (2008). Sustainable development of process facilities: Stateof-the-art review of pollution prevention frameworks. Journal of Hazardous Materials. 150, 4-20.

[15] Jeona, H., Ahna, H., Songa, I., Jeonga, H., Lee. Y., Lee, H., (2008). Absorption of sulfur dioxide by porous hydrophobic membrane contactor. Desalination. 234, 252-260.

[16] Jiao, J., Zheng, Y., (2007). A multi-region model for determining the cyclone efficiency. Separation Technology. 53, 266-73.

[17] Kohn, R., E., (1969). A Mathematical Programming Model for Air Pollution Control. Sch. Sci. Math. 487-494.

[18] Lee, K., T., Bhatia, S., Mohamed, A., R., (2005). Removal of sulfur dioxide using absorbent synthesized from coal fly ash: Role of oxygen and nitrogen oxide in the desulfurization reaction. Chemical Engineering Science. 60, 3419 - 3423.

[19] Lvovsky, K., Maddison, D., Ostro, B., Hughes, G., Pearce, D., (1998). Economic Costs of Air Pollution with Special Reference to India. National Conference on Health and Environment- World Bank study, Delhi, India. 7-9.

[20] Mahmoud, M., Halwagi, E., (1998). Pollution prevention through process integration. Clean Products and Processes.1, 5-19

[21] Mohanty, C., R., Adapalaa, S., Meikapa, B., C., (2009). Removal of hazardous gaseous pollutants from industrial flue gases by a novel multi-stage fluidized bed desulfurizer. Journal of Hazardous Materials. 165, 427-434.

[22] Mok, Y., S.,Lee, H., (2006). Removal of sulfur dioxide and nitrogen oxides by using ozone injection and absorption-reduction technique. Fuel Processing Technology. 87, 591-597.

[23] Ortiz, F., J., G., Navarrete, B., Canadas, L., Salvador, L., (2007). A technical assessment of a particle hybrid collector in a pilot plan. Chem Eng J. 127, 131-142.

[24] Papandreou, V., Shang, Z., (2008). A multi-criteria optimisation approach for the design of sustainable utility systems. Computers and Chemical Engineering.32, 1589-1602.

[25] Rao, C., S., (1994).Environmental pollution control Engineering. Wiley Estern Limited New age International Limited., ISBN 81-224-0301-8.

[26] Shaban, H.,I., Klkamel, A., Gharbi, R., (1997). An optimization model for air pollution control decision making. Environ modell softw.12, 51-58.

[27] Shanthakumar, S., Singh, D., N., Phadke, R., C., (2008). Flue gas conditioning for reducing suspended particulate matter from thermal power stations. Progress in Energy and Combustion Science. 34, 685- 695.

[28] Swanson, M., B., Davis, G., A., Kincaid, L., E., Schultz, T., W., Bartmess, J., E., Jones, S., L., George, E., L., (1997). A screening method for ranking and scoring chemicals by potential human health and environmental impacts. Environmental Toxicology and Chemistry. 16, 372-383.

[29] Wessberg, N., Molarius, R., Seppala. J., Koskela, S., Pennanen, J., (2008). Environmental risk analysis for accidental emissions. Journal of Chemical Health \& Safety. Jan- Feb,.24-31. 